\title{
Fluid management in children
}

Dr Mikey

06/10/2021 


\section{Introduction:}

- Fluid management in children is more complex than first appears.

- Very important to know why fluid is being given before giving.

- Be aware of the dangers of over-hydrating patients - pulmonary oedema etc.

- Children need to be treated with caution.

- Constant re-assessment is extremely important to avoid sudden changes in condition. 


\section{Starting point: Assessing for shock:}

- Shock in a child requires 3 clinical signs:

- 1. Fast and weak pulse (could also be slow if in severe shock).

- 2. Cold and clammy peripheries.

- 3. CRT > 3 seconds. 


\section{What is shock?}

- Shock: not getting blood carrying glucose and oxygen to important organs

- Organs don't work well without oxygen and glucose, and can be permanently damaged in shock

- Heart

- Brain

- Kidneys reduced pumping function

lethargy, irritability, coma, convulsion stop producing urine 


\section{Other helpful fluid management parameters:}

- Observe for signs of dehydration - obvious ones such as skin turgor, sunken eyes and lethargy.

- Urine output very important to monitor: this will tell you what is happening earlier than anything else.

- Beware history is not always accurate with a urine output.

- But should be monitored on the ward, forms a part of the history. 


\section{Having established shock -3 questions:}

1. Is the child anaemic?

2. Is the child malnourished?

3. Is the child dehydrated?

We are trying to establish a cause for the shock as well as looking at ways to treat. 


\section{Assessing Severe Anaemia}

- Common

- Often in children with malaria (Malaria parasites destroy red blood cells rapidly)

- Beware children bleeding

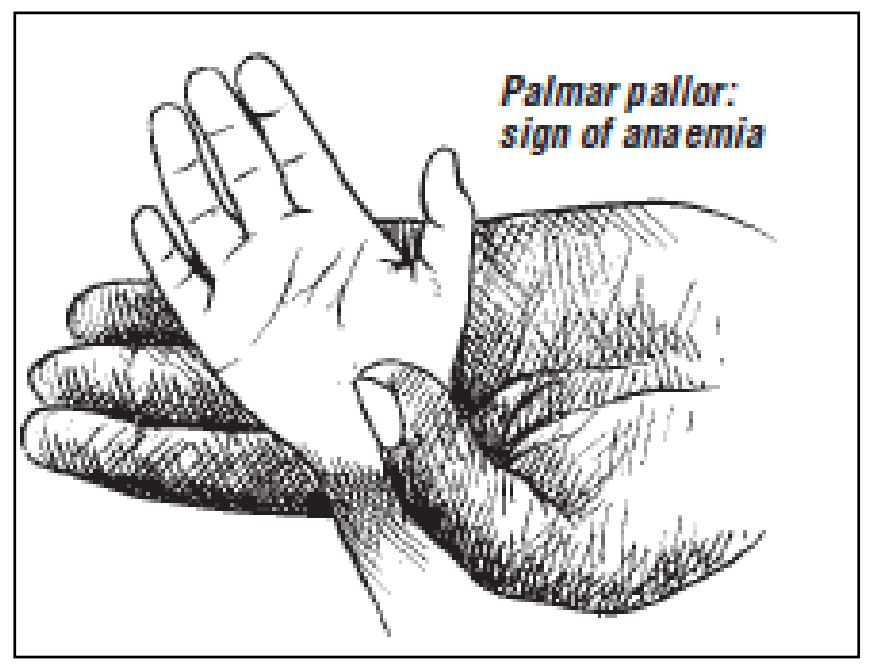
slowly via GIT.

- Severe pallor

- Low HB

- May cause cardiogenic shock

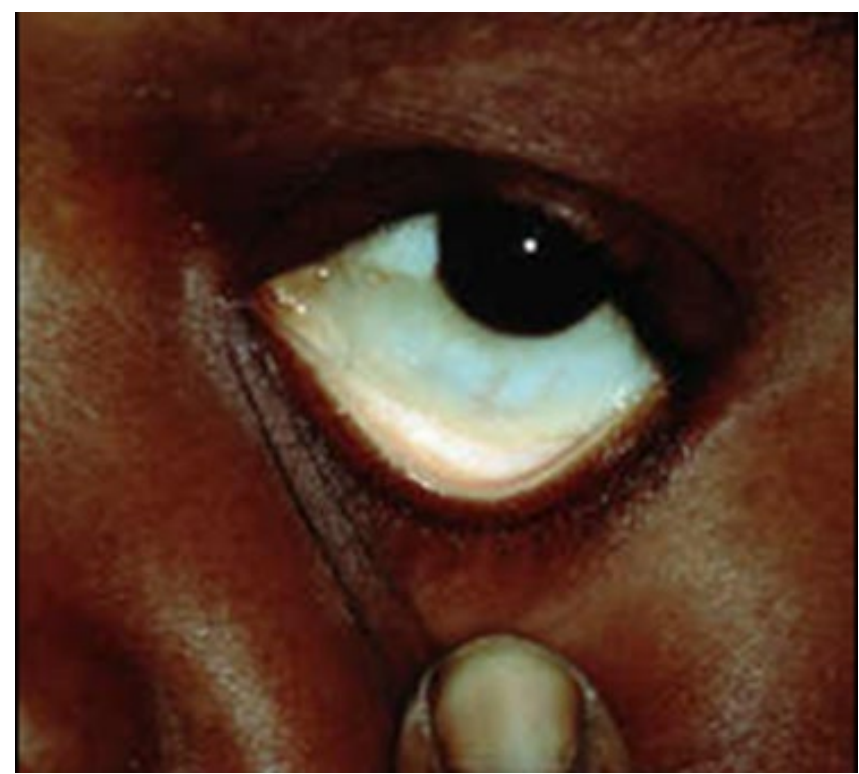




\section{Management of children with shock AND severe anaemia $(\mathrm{Hb}<6)$}

- Give blood as soon as possible

- No malnutrition: $20 \mathrm{ml} / \mathrm{kg}$ over 3-4 hours

- Severe acute malnutrition: $10 \mathrm{ml} / \mathrm{kg}$ over 3-4 hours

- Give maintenance fluid while waiting for blood 


\section{Giving a blood transfusion}

When? $\quad \mathrm{Hb}<6 \mathrm{~g} / \mathrm{dl}$ if child in shock or has signs of heart failure

$\mathrm{Hb}<\mathbf{5} \mathrm{g} / \mathrm{dL}$ for all other children

What? Whole blood or packed red cells

How much? $\quad 20 \mathrm{ml} / \mathrm{kg}$ whole blood or $10-15 \mathrm{ml} / \mathrm{kg}$ packed red cells

Half of this volume in severely malnourished children

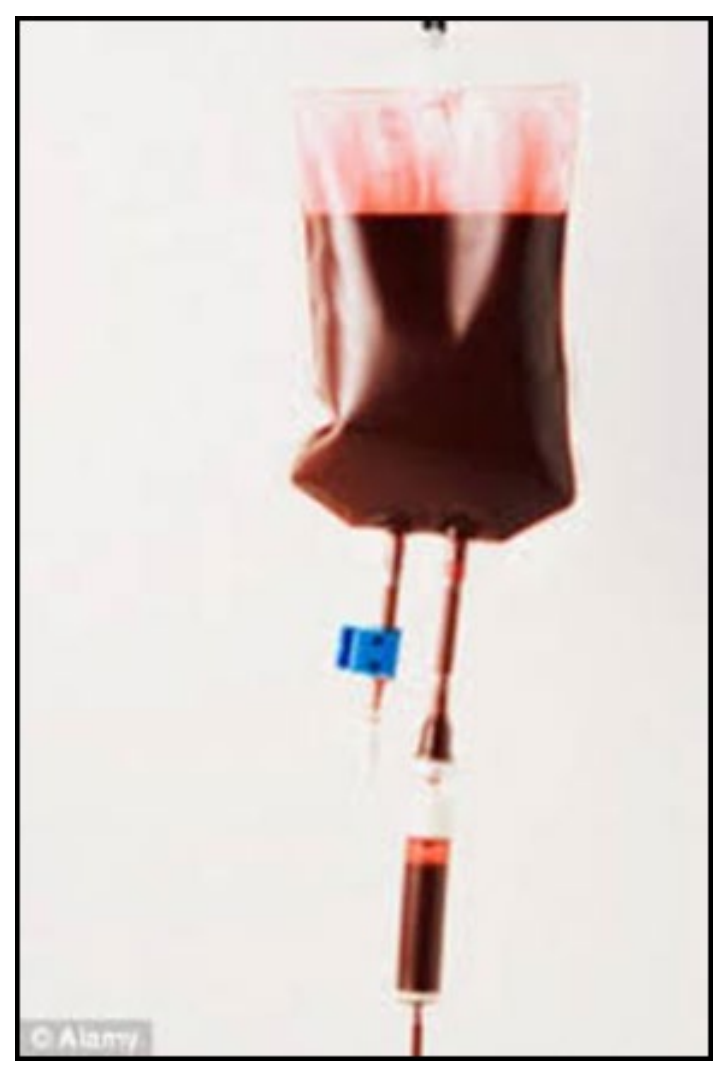

How fast? $\quad 3-4$ hrs 


\section{Assess for malnutrition: Look}

\section{Marasmus}

- Old person's face

- Irritable

- Extreme wasting and low weight

\section{Kwashiorkor}

- Apathy

- Oedema of legs, arms, face

- Pale, spare hair, weak roots

- Moon face

- Pale, thin, peeling skin

- Hepatomegaly
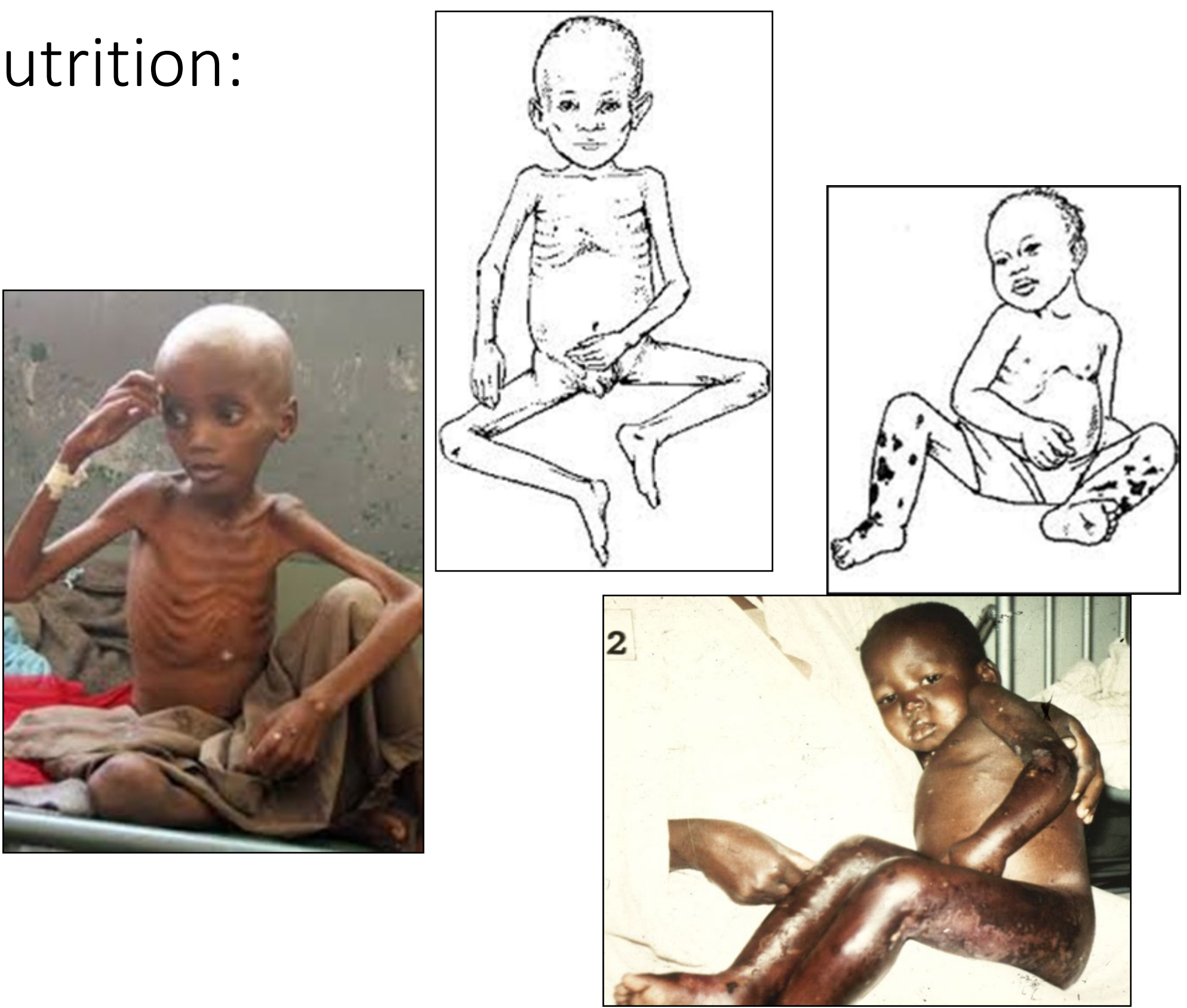
Assess for dehydration - fluid resuscitation is different 


\section{What is your assessment?}

- Normal circulation: proceed to assess Disability

- Signs of impaired circulation:

- 1. Is the child in shock? (ALL of cold hands and feet; CRT >3 secs; weak+rapid pulse)

- 2. What is the cause of the circulatory problem?

- Is the child anaemic?

- Does the child have watery diarrhoea, and are they dehydrated?

- 3. Does the child have severe acute malnutrition? 


\section{Different causes for shock}

\begin{tabular}{|l|l|l|}
\hline Cause & Mechanism & Name \\
\hline $\begin{array}{l}\text { Severe dehydration } \\
\text { Severe bleeding }\end{array}$ & $\begin{array}{l}\text { Because of fluid loss through vomiting and diarrhoea or } \\
\text { blood loss through bleeding, there is too little blood } \\
\text { volume }\end{array}$ & Hypovolaemic shock \\
\hline $\begin{array}{l}\text { Severe infection } \\
\text { bacterial (Septic shock) } \\
\text { viral (Ebola, Dengue) }\end{array}$ & $\begin{array}{l}\text { Infection can damage blood vessels and make them leaky. } \\
\text { Fluid leaks out of the vessels into the tissue (oedema) and } \\
\text { there is too little fluid left in the blood vessels (too little } \\
\text { blood volume). Infection can also damage the heart } \\
\text { muscle. }\end{array}$ & Distributive shock \\
\hline $\begin{array}{l}\text { Severe anaemia } \\
\text { (Other diseases of the } \\
\text { heart) }\end{array}$ & $\begin{array}{l}\text { Heart failure (too little oxygen in the heart muscle), the } \\
\text { heart can't pump the blood. There are too few red blood } \\
\text { cells to deliver oxygen. }\end{array}$ & $\begin{array}{l}\text { Cardiogenic shock } \\
\text { (weak heart) }\end{array}$ \\
\hline $\begin{array}{l}\text { Severe allergic reaction } \\
\text { (anaphylaxis) }\end{array}$ & $\begin{array}{l}\text { Severe allergic reactions can also make blood vessles leaky. } \\
\text { Fluid leaks into the tissue (oedema), and there is too little } \\
\text { fluid left in the blood vessels (too little blood volume) }\end{array}$ & $\begin{array}{l}\text { Anaphylactic shock } \\
\text { (leaky vessels) }\end{array}$ \\
\hline
\end{tabular}




\section{What would you see if a child is in shock?}

- Airway: The patient may be unconscious, in which case they are at risk of aspiration and obstruction

- Breathing: The patient may be hypoxic: poor blood supply to lungs to pick up oxygen

- Circulation:

- The heart beats faster: trying to increase the blood supply to the body

- The pulses become weaker

- Hands and feet become cold: what level does it stop? Wrist? Elbow?

- $\mathrm{CRT}>3 \mathrm{sec}$

- Pale

- Coma/Convulsion:

- Decreased level of conciousness, irritable, convulsion: decreased oxygen and sugar to the brain

- Blood sugar might be low

- Dehydration

- Very severe diarrhoea and dehydration will eventually cause shock 


\section{Shock treatment - cause determined:}

- Dehydration - more aggressive fluid management to be discussed later.

- Distributive - boluses as below.

- Cardiogenic - need for blood to improve oxygen to heart.

- Anaphylactic - similar plan to distributive but address the cause with anti-inflammatories. 


\section{Treatment of Shock: distributive/anaphylactic}

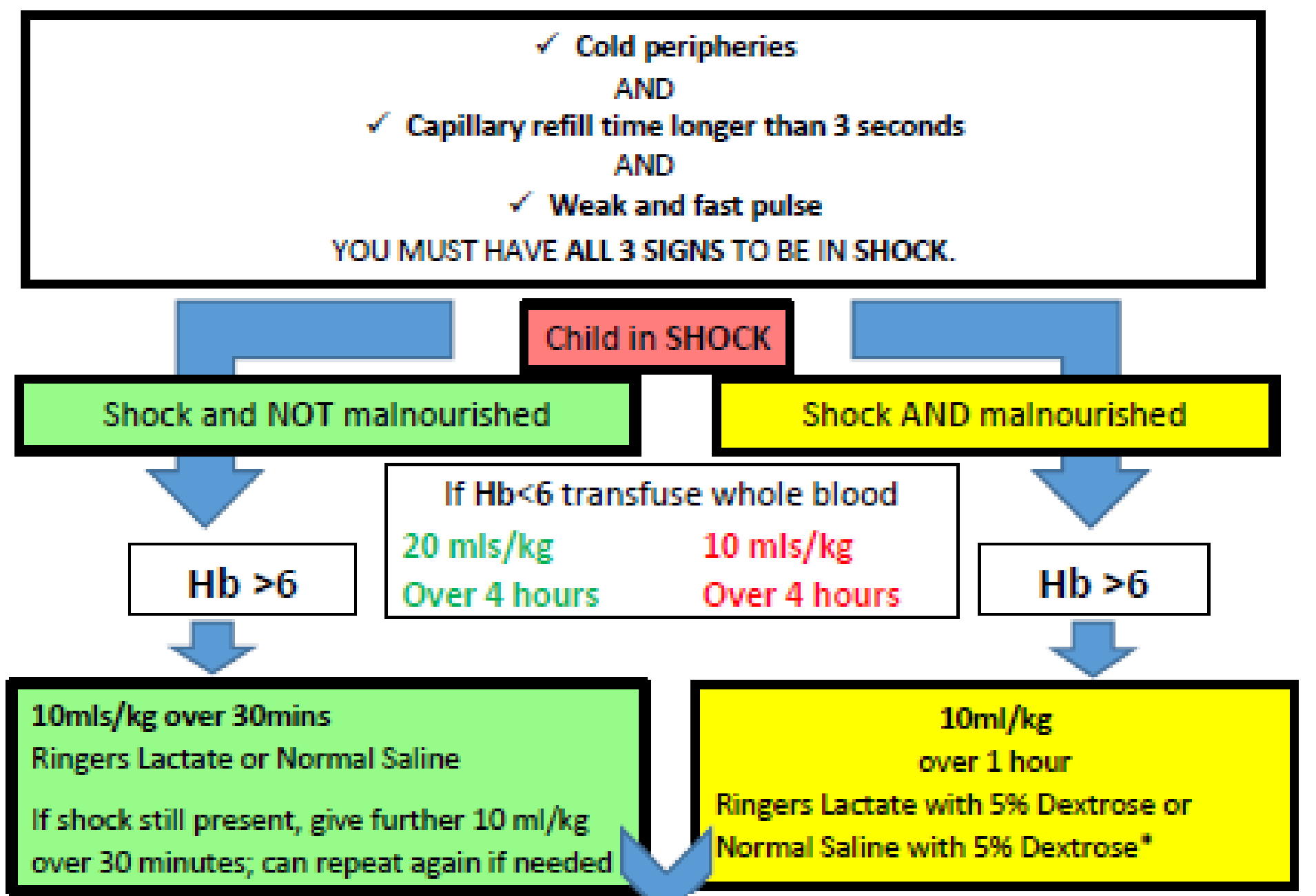


Shock and NOT Malnourished with $\mathrm{Hb}>6$

$>$ Bolus: $10 \mathrm{mls} / \mathrm{kg}$ over $30 \mathrm{mins}$

$>$ Fluid: RL or NS

$>$ Reassess after each bolus

$>$ Can be repeated $2 x$ if shock not resolved 
Shock and Malnourished with $\mathrm{Hb}>6$

$>$ Bolus: $10 \mathrm{mls} / \mathrm{kg}$ over 1 hour

$>$ Fluid: RL+D5 or NS+D5

$>$ Reassess after the bolus

$>$ The bolus should not be repeated 


\section{After the initial treatment of Shock}

\begin{tabular}{|c|c|}
\hline NO MALNUTRITION & SEVERE MALNUTRITION \\
\hline $\begin{array}{l}\text { If shock not secondary to diarrhoea: } \\
\text { SHOCK RESOLVED: Give maintenance fluids or } \\
\text { feeds following the protocol below } \\
\text { SHOCK PERSISTS: Give maintenance fluids AND } \\
\text { Consider blood transfusion }\end{array}$ & $\begin{array}{l}\text { If shock not secondary to diarrhoea: } \\
\text { SHOCK RESOLVED: Start NG/oral ReSoMal } \\
\text { following Step } 2 \text { for malnourished children } \\
\text { SHOCK PERSISTS: Start NG/oral ReSoMal } \\
\text { following Step } 2 \text { for malnourished children } \\
\text { AND } \\
\text { Consider blood transfusion }\end{array}$ \\
\hline
\end{tabular}

\section{SHOCK SECONDARY TO DIARRHOEA}

NO MALNUTRITION: Follow Severe Dehydration Step 2

SEVERE MALNUTRITION: Start NG/oral ReSoMal following Step 2 for malnourished children 


\section{After the initial treatment: Shock not secondary to dehydration}

- Child not malnourished:

Shock resolved:

- Give IV maintenance fluid or NG/PO feeds

- Shock not resolved:

- Give maintenance fluid

- AND

- Consider blood transfusion 


\section{After the initial treatment: \\ Shock not secondary to dehydration}

- Child Malnourished

- Shock resolved:

- Give NG/PO ReSoMal following step 2 for the child with SAM

- Shock not resolved:

- Give NG/PO ReSoMal following step 2 for the child with SAM

- AND

- Consider blood transfusion 


\section{What is IO cannulation?}

Inserting a line into the marrow cavity providing access to noncollapsible venous plexus
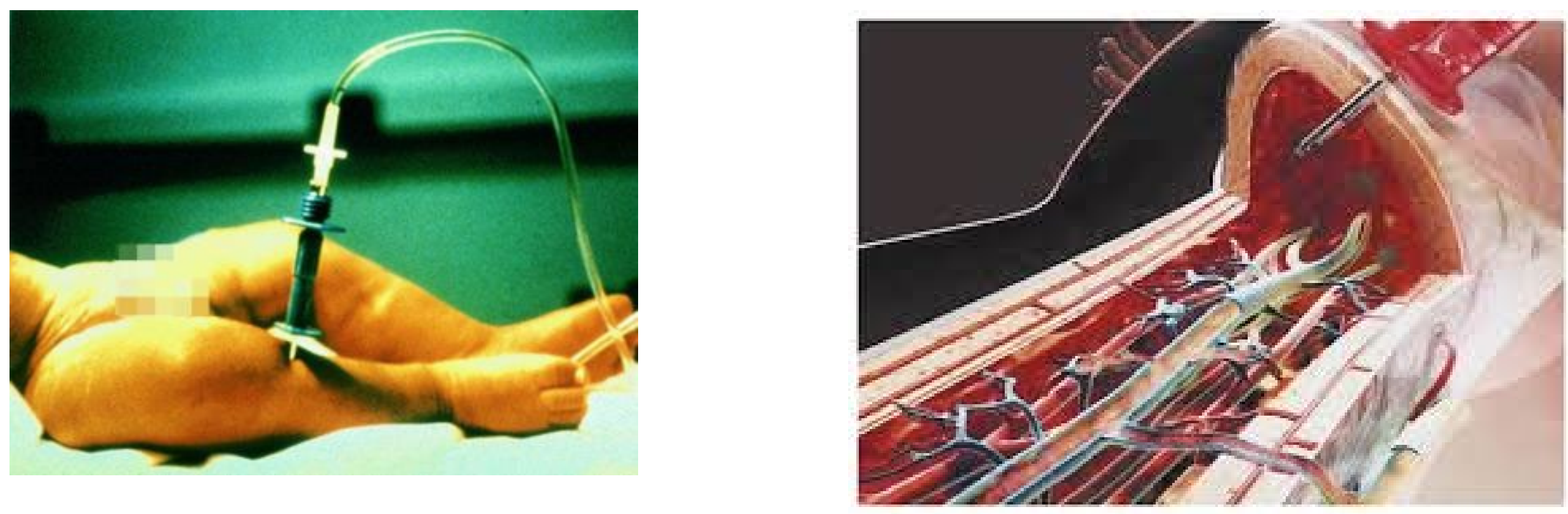


\section{Site}

- Sternum

- Humerus

- Femur

- Tibia-proximal and distal

- Ilium
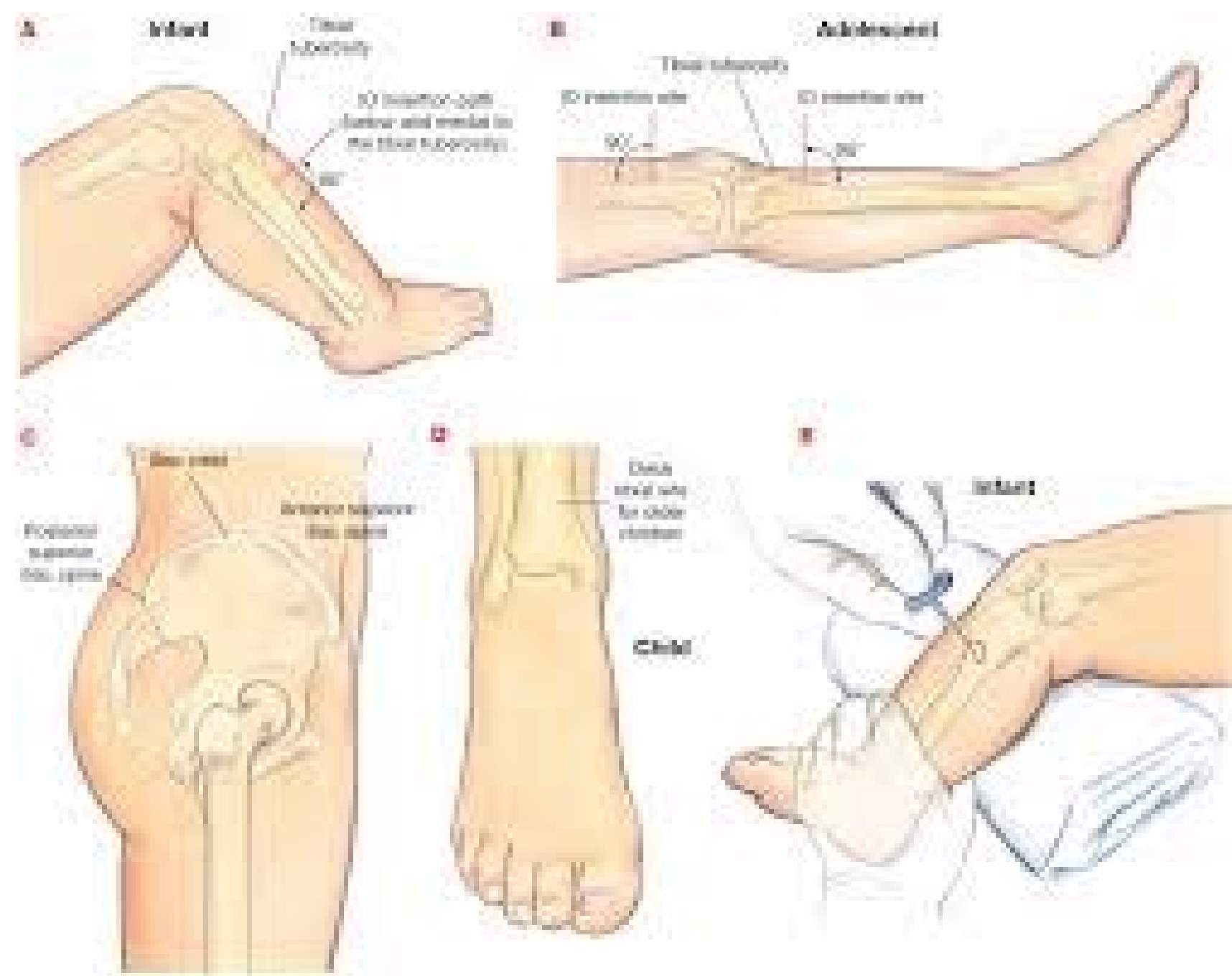


\section{Tibia}

- Proximal or distal

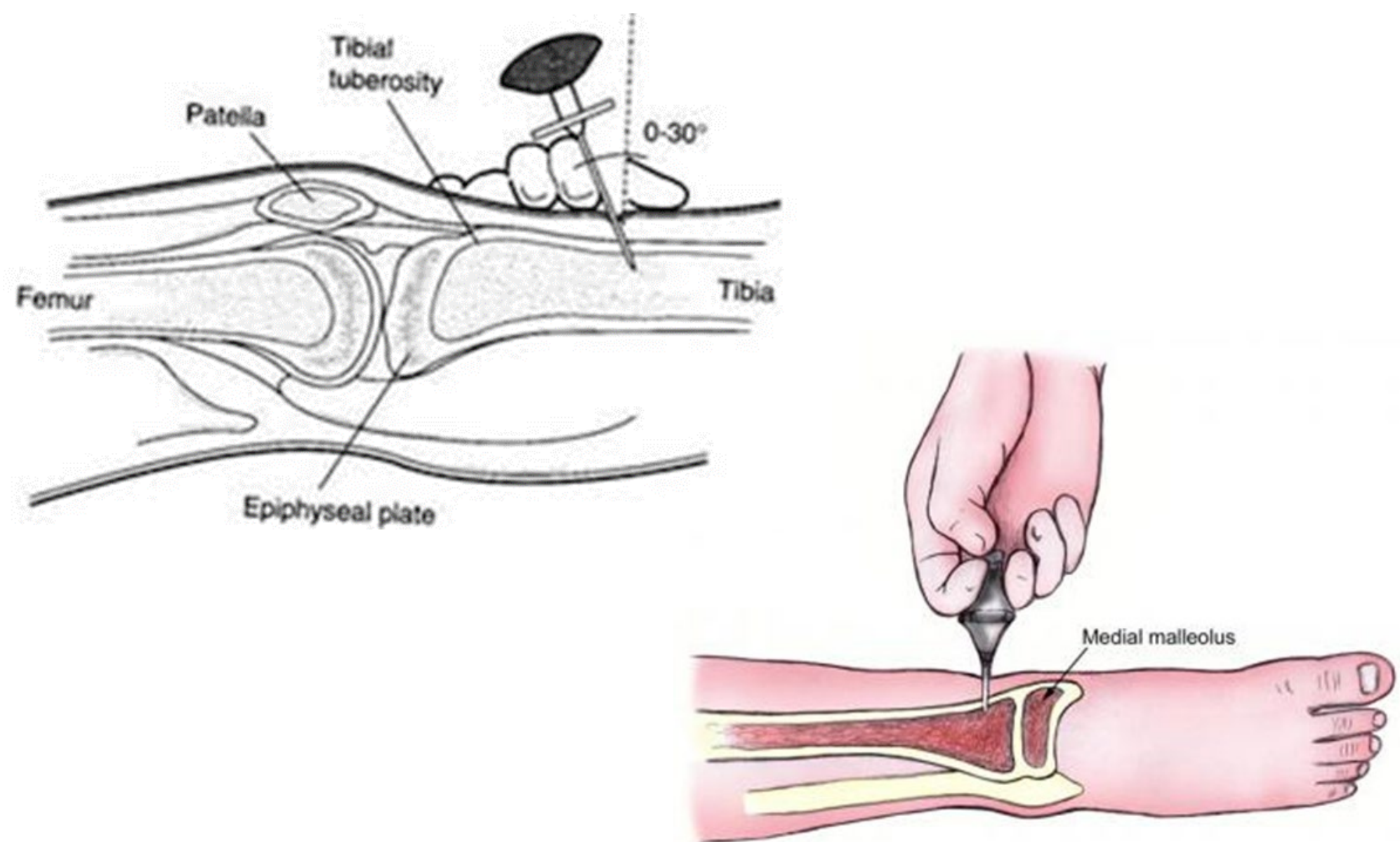




\section{Types of 10}
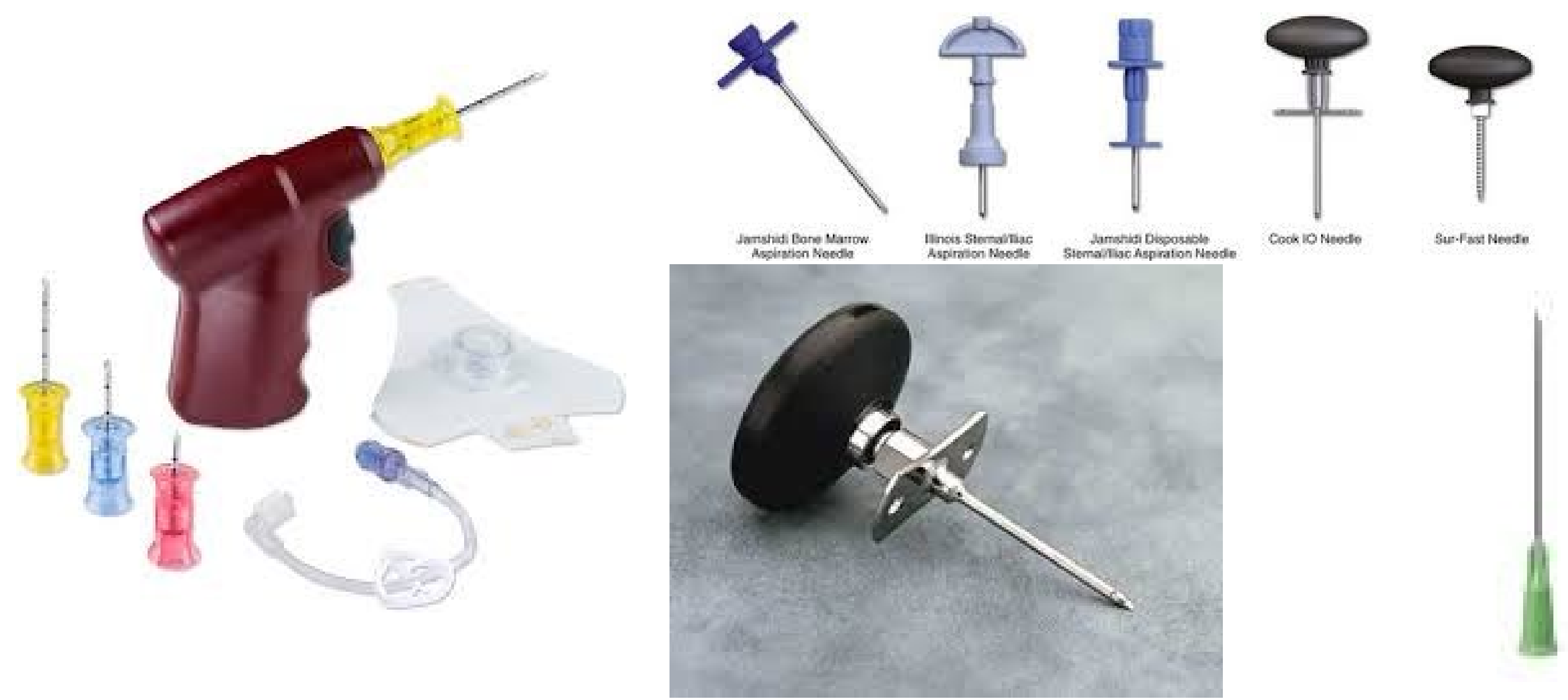


\section{Contraindications}

- Distal trauma (fracture on the same side)

- Infection

- Previous attempt on the same site

- Osteogenesis imperfecta

- Bleeding problems (relative contraindication) 


\section{Reason for failure}

- Incorrect identification of landmarks

- A bent needle

- Clogging of the needle with marrow

- Through-and-through penetration of both anterior and posterior cortices

- Fractures caused by excess force or by fragile bones

- Penetration of the mediastinal structures or space with the potential for pneumothorax, vascular injury, lung injury, in the case of a sternal needle 


\section{Complications}

- Local infection

- Compartment syndrome secondary to fluid extravasation

- Local hematoma

- Pain

- Potential for growth plate

- Fat embolus

- Bone embolus (though this has not been reported in humans)

- Mediastinitis after sternal IO puncture 


\section{Watery Diarrhoea}

- In small children, diarrhoea is usually caused by viruses, and not by bacteria

- These viruses are highly infectious, and easily spread between people 


\section{Watery Diarrhoea}

- Diarrhoea (frequent watery stool)

- Vomiting (not always)

- Might be unable to drink

Fluid loss

- Low grade fever

Treatment:

- Rehydration (PO,NG or IV)

- Zinc

- Advise to feed continuously

- ANTIBIOTICS ONLY IF BLOODY DIARRHOEA 


\section{How to assess dehydration Look; Feel: signs of dehydration}
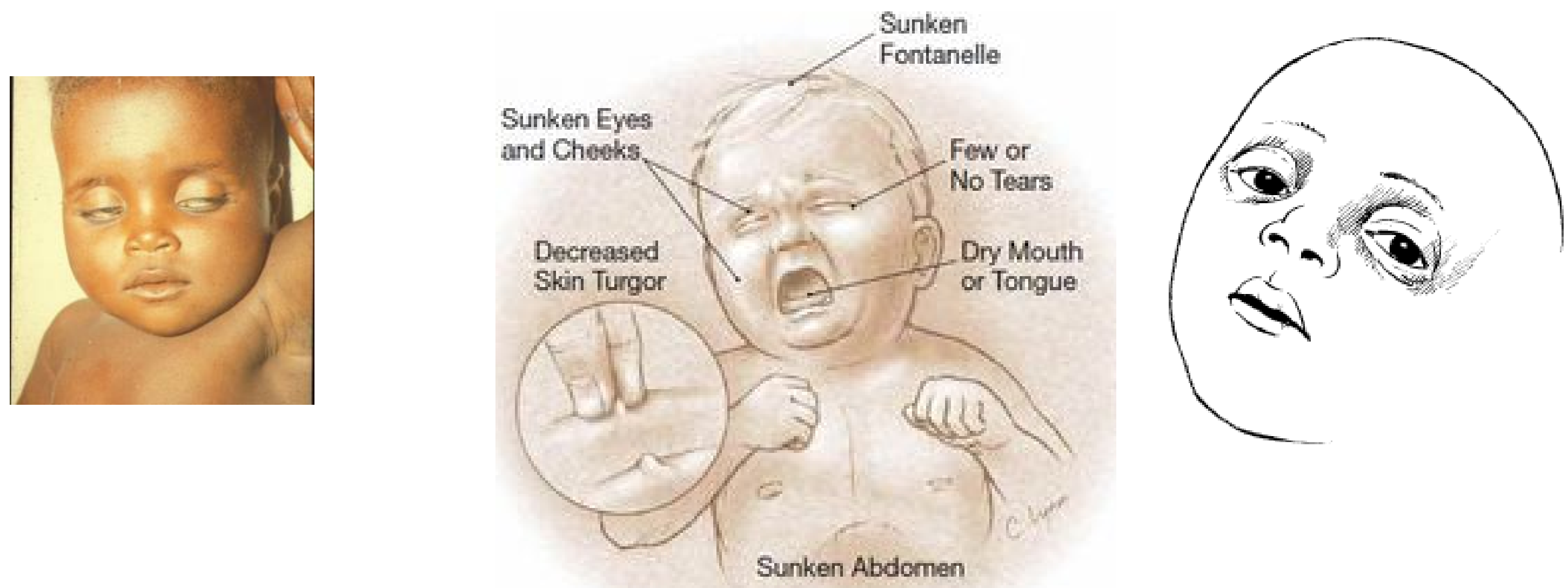


\section{Skin pinch}
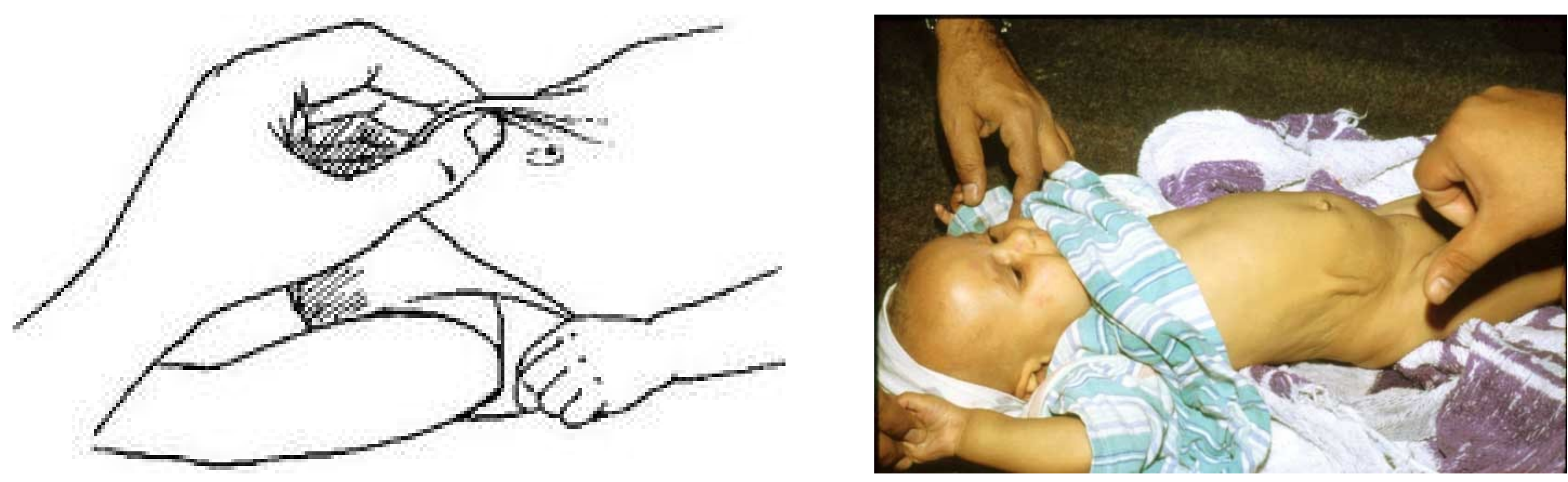


\section{Grades of Dehydration}

$>$ No Dehydration (no signs of dehydration)

\section{$>$ Some Dehydration}

$>$ Severe Dehydration 


\section{Emergency signs for severe dehydration}

-Watery diarrhoea and

- 2 out of the 4: Lethargy

Sunken eyes

Very slow skin pinch

Unable to drink 
Dehydrated and NOT malnourished

Ringer's Lactate, Normal Saline Use DNS for dehydration only is RL or NS is not available

INFANTS (under 1 year)

Step 1: $\mathbf{3 0} \mathrm{ml} / \mathbf{k g}$ in the first hour

Step 2: $70 \mathrm{ml} / \mathrm{kg}$ in the next 5 hours

CHILDREN (over 1 year)

Step 1: $\mathbf{3 0} \mathrm{ml} / \mathrm{kg}$ in the first $\mathbf{3 0 \mathrm { min }}$

Step 2: $70 \mathrm{ml} / \mathbf{k g}$ in the next 2.5hours 


\section{Treatment of severe dehydration (not in shock) in malnourished children}

- Signs of dehydration are difficult to assess in malnourished children

- The heart muscle is weak and wasted, so giving IV fluids in large amounts is dangerous

- Oral rehydration with ReSoMal:

- $5 \mathrm{ml} / \mathrm{kg}$ for every $30 \mathrm{~min}$ for the first 2 hours

- 5-10 ml/kg per hour for the next 4 to 10 hours (in between F75, every 2 hours

- Every child with SAM and diarrhoea should receive ReSoMal (treatment or prevention of dehydration) 
Dehydrated AND malnourished

ReSoMal oral
- Step 1: $\mathbf{5 m l} / \mathbf{k g}$ every $\mathbf{3 0}$ minutes for
the first 2 hours
- Step 2: 5 to $10 \mathrm{ml} / \mathrm{kg}$ every hour for
the next 4 to 10 hours. If possible,
alternate $\mathrm{F} 75,5 \mathrm{mls} / \mathrm{kg}$, with
ReSoMal
If child unable to tolerate oral or $N G$
fluids, consider careful IV rehydration
with $R L+D 5$




\section{Dehydration}

\section{Watery diarrhoea +2 of the following:}

\section{SEVERE}

- Sunken eyes

- Lethargic

- Very slow skin pinch (>2sec)

- Unable to drink

\section{SOME}

- Sunken eyes

- Restless

- Slow skin pinch (<2 sec)

- Thirsty 


\section{WATERY DIARRHOEA +2 out of the 4 :}

- Restless, irritable

- Sunken eyes

- Slow skin pinch (<2 seconds)

- Thirsty/drinks eagerly

If child not in shock but has some dehydration:

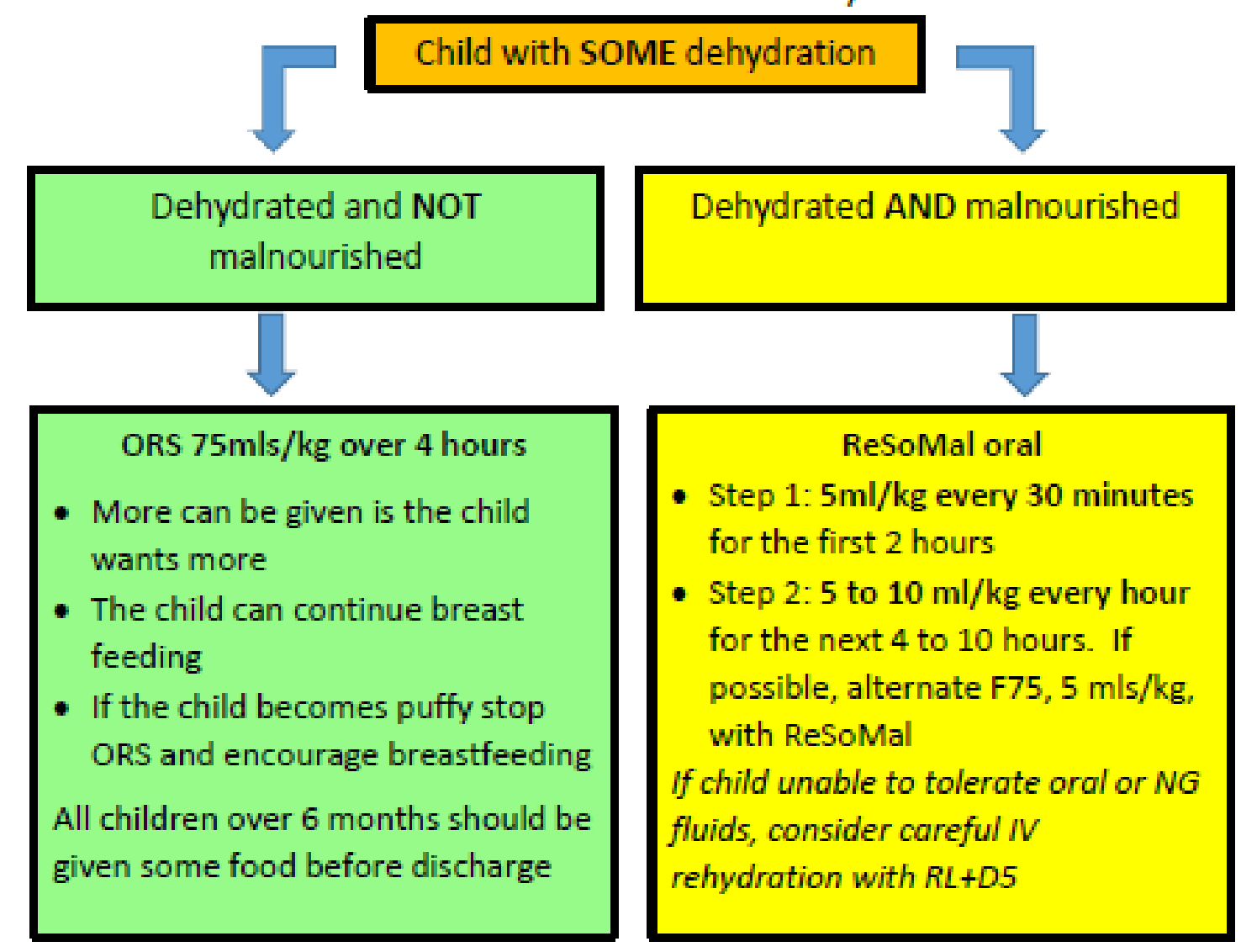




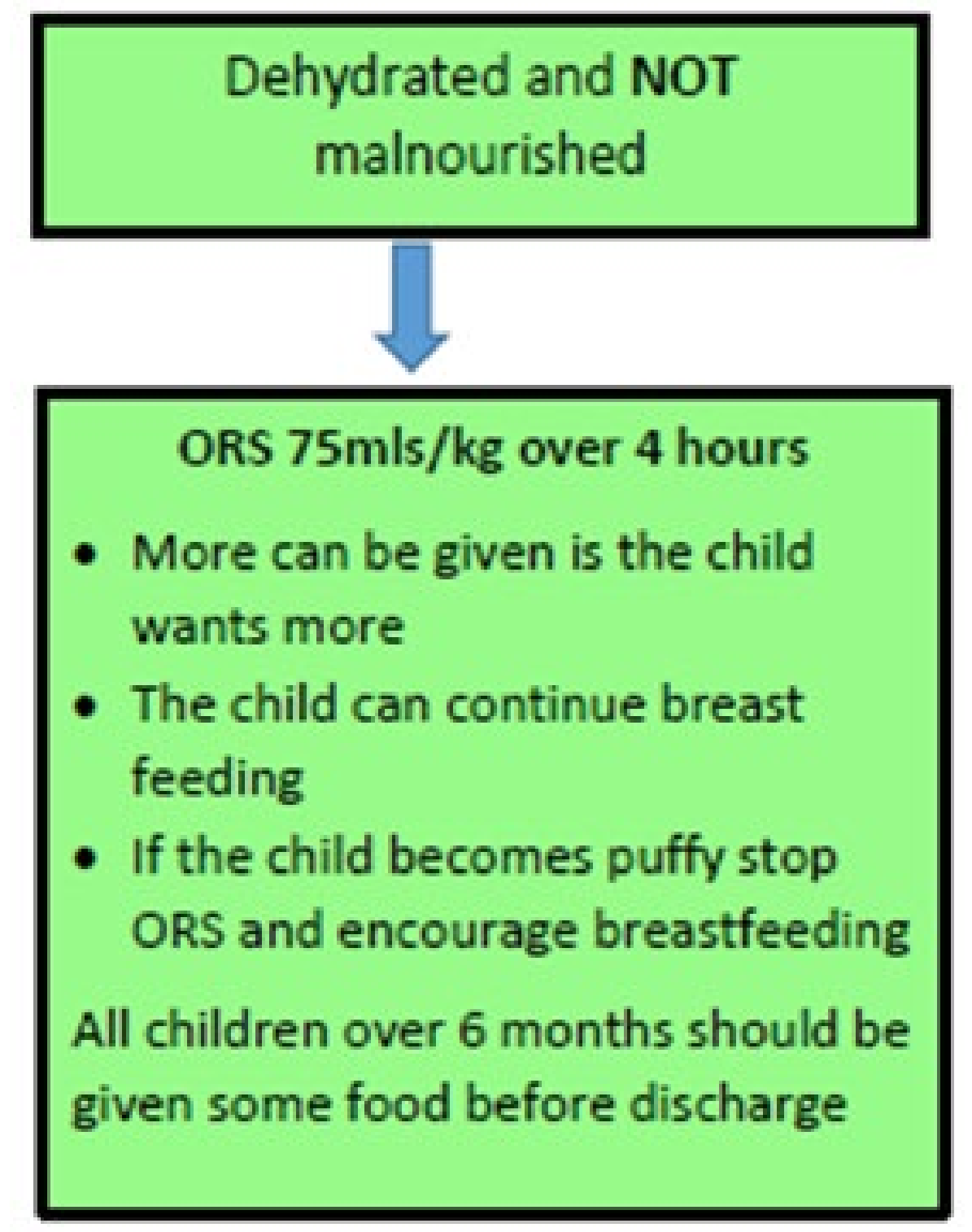


Dehydrated AND malnourished

ReSoMal oral
- Step 1: $\mathbf{5 m l} / \mathbf{k g}$ every $\mathbf{3 0}$ minutes for
the first 2 hours
- Step 2: 5 to $10 \mathrm{ml} / \mathrm{kg}$ every hour for
the next 4 to 10 hours. If possible,
alternate $\mathrm{F} 75,5 \mathrm{mls} / \mathrm{kg}$, with
ReSoMal
If child unable to tolerate oral or $N G$
fluids, consider careful IV rehydration
with $R L+D 5$




\section{Fluid management: summary}

\begin{tabular}{|c|c|c|}
\hline & Not malnourished & Malnourished \\
\hline Shock (all 3 features) & $\begin{array}{l}\text { IV } \\
10-20 \mathrm{mls} / \mathrm{kg} \text { RL/NS over } 1 \text { hour } \\
(10 \mathrm{mls} / \mathrm{kg} \text { over } 30 \mathrm{mins} \text { can be } \\
\text { repeated } 2 \mathrm{x})\end{array}$ & $\begin{array}{l}\text { IV } \\
\mathrm{RL}+\mathrm{D} 5 \% \text { 10-15mls/kg over } 1 \mathrm{hr}\end{array}$ \\
\hline Severe dehydration & $\begin{array}{l}\text { IV } \\
30 \mathrm{mls} / \mathrm{kg} \text { RL/NS/DNS: }<1 \mathrm{yr} \text { over } 1 \\
\mathrm{hr},>1 \mathrm{yr} \text { over } 30 \mathrm{mins} \\
70 \mathrm{mls} / \mathrm{kg} \mathrm{RL} / \mathrm{NS} / \mathrm{DNS}:<1 \mathrm{yr} \text { over } \\
5 \mathrm{hrs},>1 \mathrm{yr} \text { over } 2.5 \mathrm{hrs}\end{array}$ & $\begin{array}{l}\text { PO/NG } \\
\text { ReSoMal } 5 \mathrm{mls} / \mathrm{kg} \text { every } 30 \mathrm{~min}\end{array}$ \\
\hline Some dehydration & $\begin{array}{l}\text { PO/NG } \\
\text { ORS } 75 \mathrm{mls} / \mathrm{kg} \text { over } 4 \text { hours }\end{array}$ & $\begin{array}{l}\text { PO/NG } \\
\text { ReSoMal } 5 \mathrm{mls} / \mathrm{kg} \text { every } 30 \mathrm{~min}\end{array}$ \\
\hline $\begin{array}{l}\text { Impaired circulation (some but }<3 \\
\text { features of shock) }\end{array}$ & $\begin{array}{l}\text { IV } \\
\text { Maintenance }\end{array}$ & $\begin{array}{l}\text { PO/NG } \\
\text { ReSoMal } 5 \mathrm{mls} / \mathrm{kg} \text { every } 30 \mathrm{~min}\end{array}$ \\
\hline
\end{tabular}




\section{Maintenance Fluid and Feeds}

Which children need maintenance fluid?

- Any child who is nil by mouth (NPO):

- Severe respiratory distress

- Bowel obstruction (perforation, septic ileus....)

- AVPU and at high risk of aspiration

-Well nourished children with impaired circulation (some, but not all 3 features of shock) 


\section{What fluid to give?}

- Most children should receive fluid containing dextrose

- Normally Dextrose Normal Saline (DNS)

- or

- Ringer Lactate with 5\% Dextrose

- For short periods, it is possible to use Ringer's Lactate: make sure to check the blood glucose level!

- YOU MUST NEVER GIVE ONLY D5\% 


\section{How much fluid to give?}

- In order to calculate the child's IV maintenance fluids over 24 hours:

- Use the weight of the child

- $1^{\text {st }} 10 \mathrm{~kg}: 100 \mathrm{ml} / \mathrm{kg}$

- $2^{\text {nd }} 10 \mathrm{~kg}: 50 \mathrm{ml} / \mathrm{kg}$

- Any further kg: $25 \mathrm{ml} / \mathrm{kg}$ 


\section{Calculating how much fluid/feed to give over 24 hours}

- $12 \mathrm{~kg}$ child:

- $10 \mathrm{~kg} \times 100 \mathrm{ml}=1000 \mathrm{ml}$

- $2 \mathrm{~kg} \times 50 \mathrm{ml}=100 \mathrm{ml}$

- Total over 24 hours $=1100 \mathrm{ml}$ 


\section{Calculating how much fluid/feed to give over 24 hours}

- $24 \mathrm{~kg}$ child

- $10 \mathrm{~kg} \times 100 \mathrm{ml}=1000 \mathrm{ml}$

- $10 \mathrm{~kg} \times 50 \mathrm{ml}=500 \mathrm{ml}$

- $4 \mathrm{~kg} \times 25 \mathrm{ml}=100 \mathrm{ml}$

- Total over 24 hours $=1600 \mathrm{ml}$ 


\section{Calculating 3 hourly feeds}

- $24 \mathrm{~kg}$ child: $1600 \mathrm{ml}$ in 24 hours

- 3 hourly feeds $=8$ feeds in 24 hours

- $1600 / 8$ feeds $=200 \mathrm{ml}$ per feed 


\section{Hypoglycaemia:}

- Ideally less than $70 \mathrm{mg} / \mathrm{dl}$ should be treated.

- Avoid further hypoglycaemic events by managing fluids and feeds effectively.

- Consider hypoglycaemia to be a sign of either malnutrition, sepsis or another serious underlying condition.

- Treat with D10\% 5mls per kg. 


\section{Summary}

- Fluid loss from diarrhoeal disease can kill if the fluid is not replaced

- It is important to make a careful assessment of the degree of dehydration, using the most reliable signs

- Severe dehydration is an emergency sign, and requires immediate action

- Treatment will differ, depending on whether or not the child is malnourished

- It is important to make a plan for the child's ongoing fluid requirements, and to calculate and prescribe the fluids for the first 24 hours of admission 